\title{
Terceira Carta de Chklóvski
}

\author{
Neide Jallageas
}

Resumo: Esta é uma das cartas que compõem o livro ZOO. Cartas não sobre o amor, ou Terceira Heloisa, de Vik.tor Borisovitch Chklóvski (São Petersburgo, 1893-1984). Publicada pela primeira vez. em 1923, em Berlim, ela é traduzida aqui diretamente do russo.

Palavras-chave: Literatura Russa; tradução

\section{Introdução}

Esta é uma das cartas que compõem o livro ZOO. Cartas não sobre o amor, on Terceira Heloisa, de Víktor Borísovitch Chklóvski (São Petersburgo, 1893-1984), publicado pela primeira vez em 1923, em Berlim. Chklóvski encontrava-se exilado na capital alemã onde também estava Elsa Triolet (1896-1970) que, junto ao contexto, inspirou ao escritor na criação deste romance epistolar, composto de fragmentos que se conectam por meio de metáforas do amor (que passa a ser dirigido à Rússia, pátria distante), já que o missivista apaixonado por Alia/Elsa, logo de início, fora impedido por sua amada de escrever sobre o amor. A "Terceira Carta" é exatamente a que contém a interdição dirigida ao escritor, assinada pela mulher amada e que recusa esse amor.

A presente tradução, realizada diretamente do russo, é inédita.

A tradutora agradece a leitura atenta e observações de Ekaterina Volkova Américo para esta tradução. 


\section{ZOO. Cartas não sobre o amor, ou Terceira Heloisa (Viktor Chkló- vski)}

\section{TERCEIRA CARTA}

Segunda carta também de Alia.

Nela, Alia pede para que eu não escreva a ela sobre o amor.

Caro, meu querido. Não me escreva sobre o amor. Não precisa.

Estou muito cansada. Como você mesmo disse, entreguei os pontos. Seu dia a dia nos separa. Não amo você e não amarei. Seu amor me amedronta; algum dia você me ofenderá por me amar tanto. Pare com esse terrível lamento, pois você é meu, apesar de tudo. Não me assuste! Você me conhece muito bem, mas tudo faz para me assustar, para me afastar de você. O seu amor pode ser grande, mas não é alegre.

Eu preciso de você, você sabe como despertar a minha própria face.

Não me escreva apenas sobre o seu amor. Não me ligue para fazer cenas absurdas. Não seja cruel. Você sabe como envenenar os meus dias. Eu preciso de liberdade, que ninguém ouse me perguntar qualquer coisa. Mas você exige de mim todo o meu tempo.

Seja leve, para não se perder no amor. A cada dia sua tristeza aumenta.

Você precisa descansar, meu caro.

Escrevo na cama, de tanto que dancei ontem. Agora vou tomar um banho. Talvez hoje nos vejamos.

Alia 


\section{ZOO. Письма не о мюбви, или Третья Элоиза (Шкиовский Виктор)}

\section{ПИСЬМО ТРЕТЬЕ}

А^ино же второе.

В нем А^я просит не писать ей о Аюбви. Письмо усталое.

Милый, родной. Не пиши мне о Аюбви. Не надо.

Я очень устала. У меня, как ты сам говориц, сбита холка. Нас разъединяет с тобой быт. Я не Аюблю тебя и не буду Аюбить. Я боюсь твоей

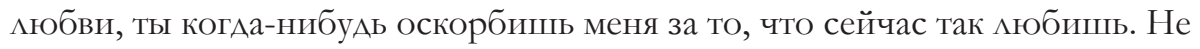
стони так страшно, ты для меня все же свой. Не пугай меня! Ты меня так хорошо знаешь, а сам делаешь все, чтобы испугать меня, оттолкнуть от себя. Может быть, твоя Аюбовь и большая, но она не радостная.

Ты нужен мне, ты умеешь вызвать меня из себя самой.

Не пиши мне только о своей Аюбви. Не устраивай мне Аиких сцен по телефону. Не свирепей. Ты умеешь отравцять мне Ани. Мне нужна свобода, чтобы никто Ааже не смел меня спрашивать ни о чем. А ты требуешь от меня всего моего времени. Будь цегким, а не то в Аюбви ты сорвешься. А ты с каждым днем все грустней. Тебе нужно ехать в санаторий, мой дорогой.

Пишу в кровати, оттого что вчера танцевала. Сейчас пойду в ванну. Может быть, сегодня увидимся.

5 февраля

\section{Referências}

CHKLÓVSKI, Víktor Borísovitch. "ZOO. Pisma ne o liubvi, ili trtia Eloiza”. São Petersburgo: Azbuka-klassika, 2009. 